\title{
Teaching Speaking Skills in Communication Classroom
}

\author{
Shafaat Hussain \\ Assistant Professorof Journalism and Communication, MaddaWalabu University, Bale Robe, Ethiopia
}

\begin{abstract}
Language is first and foremost a spoken and not a written entity. Human beings talked and listened ages before there was anything for them to read. This is why it is said that in the long history of the human race, the invention of writing was an event of yesterday. Speaking is a major skill in communication. This review article highlights how the skill of speaking is taught in communication classroom; what are the prominent beliefs about the speaking skill; what are the principles of learning and teaching speaking skills; the different activities and tasks associated to enhance the communication skill and finally, how to teach pronunciation to the learners of communication.
\end{abstract}

Keywords: Journalism and communication, classroom, speaking skill, pronunciation, Oral skill

\section{INTRODUCTION}

Language is primarily speech. A very large number of languages in the world are only spoken with no writing script. Majority of languages even with writing scripts use their spoken forms more than the written ones. It is an agreed fact that language is learnt by speaking it first after a lot of listening to the sounds, words, phrases and sentences from the surroundings (Anuradha, Raman \&Hemamalini2014). Listening and speaking are the fundamental skills, and if only the foundation is firm, the edifice built on it will be durable. In mother tongue, children get a very natural opportunity of listening and speaking in their surroundings. Thereafter, they are sent to the school to learn reading and writing skills. But, in the case of communication classroom, the available environment of the learner is mother tongue in his surroundings; therefore, the teaching learning strategy should differ greatly. Hence, there is a dire need of paradigm shift on teaching and learning speaking skill through focus deviation towards oral orientation, training the teachers, and developing suitable curriculum (Suchdeva 2011).

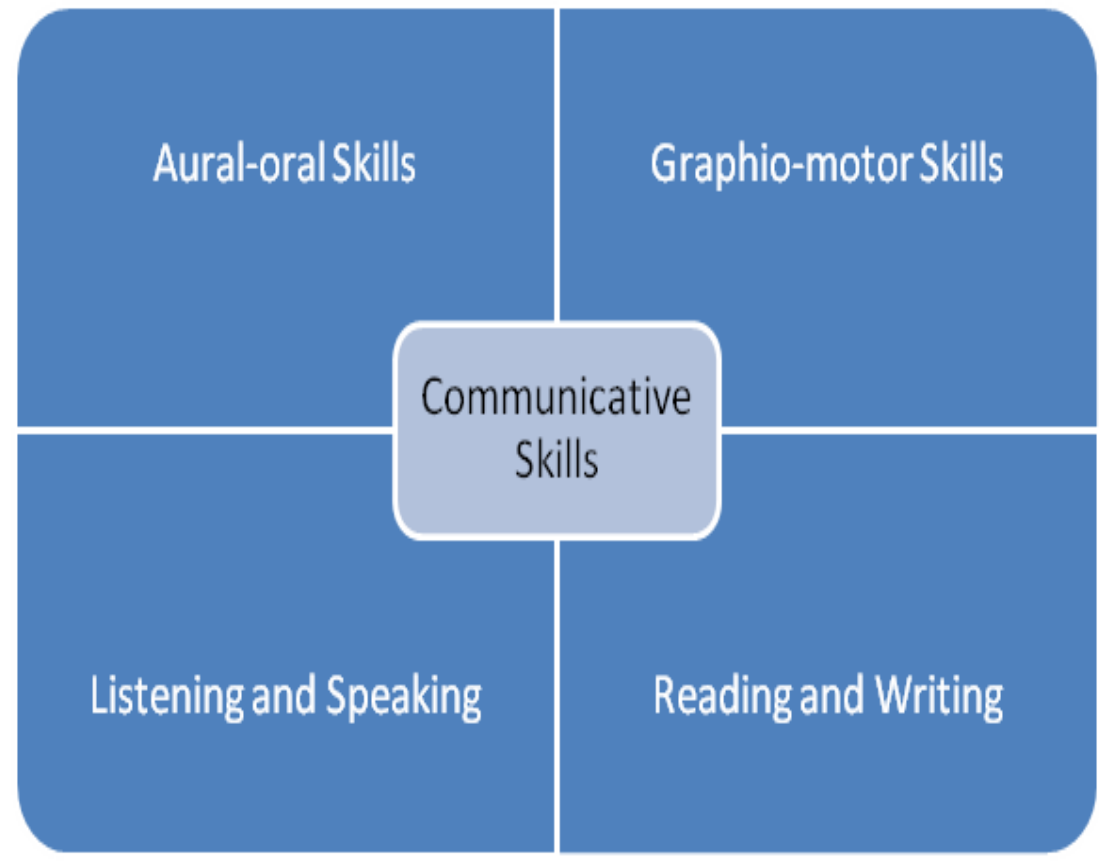

Figure1. Adapted from Rao \& Jyotsna (2009) 


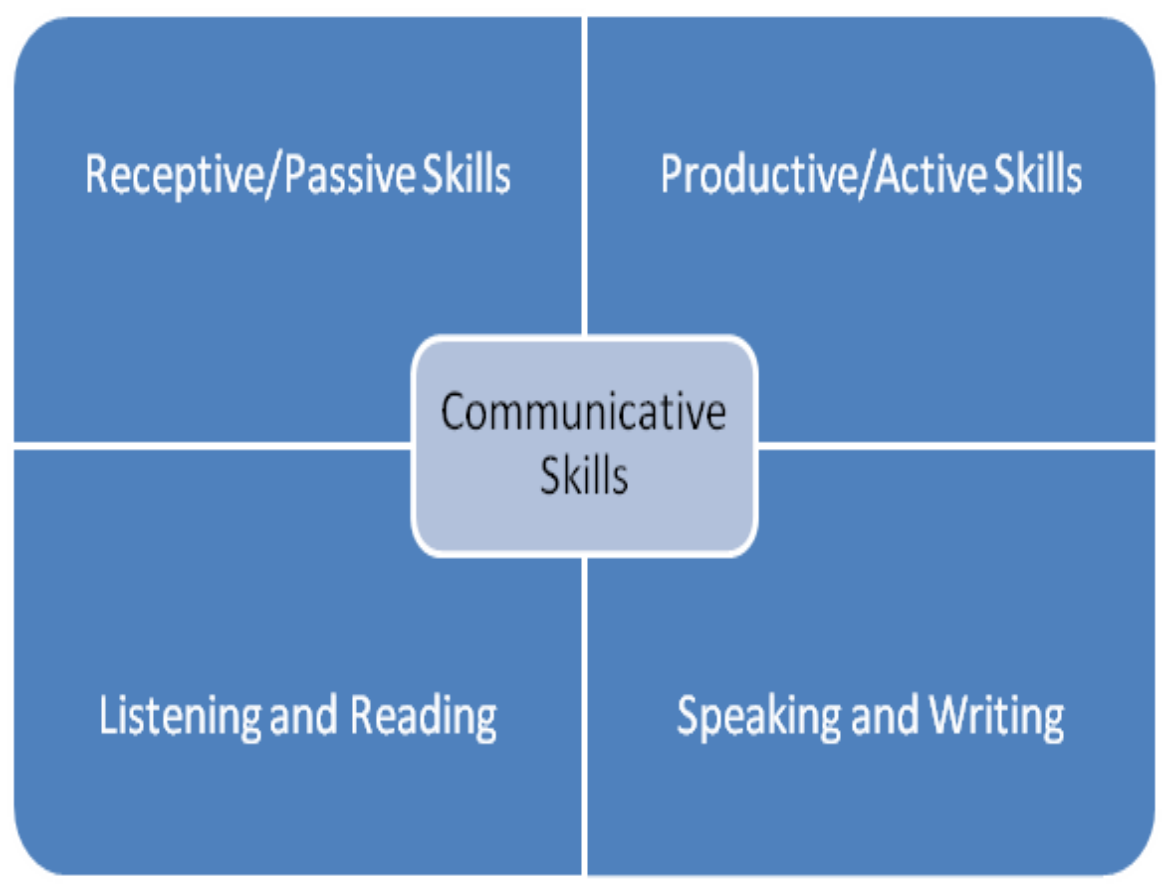

Figure2. Adapted from Rao\&Jyotsna (2009)

\section{Beliefs about DeVeloping SPEaking Skills}

According to Rao (2012), the experts believe about developing skills that:

- Of the four skills, listening and speaking are taught and learnt in quick succession. The teacher introduces the language item in the class and the learners situationalize it;

- Speech is the best introduction to other language learning skills. Learning through speaking is a natural way of learning a foreign language;

- Speech is important because it provides the opportunity for the practical usage of a foreign language;

- Speech brings fluency, correction then accuracy among EFL learners; and

- It enables the teacher to use the class time economically.

\section{Principles of Teaching Speaking Skills}

According to Anuradha et al (2014), following are the principles of teaching speaking skills:

- Encourage students to speak right from the first day. If not, as early as possible and not to wait till she teaches them a stock of words, phrases or sentences.

- Tolerate the students if some of them simply repeat what they say.

- If a student gives one word answer to any question, bear it for the time being.

- Let the learners speak actively with whatever English knowledge they have.

- Propose structures/phrases/words and let the learners use it in different situation and drill as much as possible.

- Encourage back-chaining or tail-forwarding technique to make long sentences by combining more than ten sentences.

- Organize role play and pair-work as much as possible and supervise the learners to correct the active ones and activate the passive ones.

- Be well prepared in advance in terms of lesson planning, activities and tasks.

- Let the learners commit errors and mistakes at the primary stage. Interruption and correction hinder fluency and discourage the learner. 
- Individual weaknesses should be taken into account and the teacher should be sympathetic in outlook for individual attention.

\section{Classroom Activities and Tasks for Practicing Speaking Skills}

Repetition of rhymes, look and say, oral composition, pronunciation drills, read aloud, open ended stories, narration, description (festivals, celebrations, occasions) are important practices to improve speaking skills (Jyothsna\&Rao 2009). Moreover, according to Kumari (2014), a variety of function based activities and tasks can be used to develop speaking skills which are given as under:

\subsection{Dialogue}

Dialogue is a classroom technique used for practicing functions of language like greeting, agreeing, disagreeing, apologizing, suggesting, asking information etc.

\section{Example}

\begin{tabular}{|l|l|}
\hline \multicolumn{1}{|c|}{ A } & \multicolumn{1}{|c|}{ B } \\
\hline Hello Workenish! & HellowAsanti! \\
How are you doing? & Fine, thank you. \\
Where are you going? & To the library, will you come with me? \\
I am sorry; I am going to submit my assignment. & Okay, no problem. Can you come my home this evening? \\
Anything special? & Yes, today is my birth day. \\
Oh really, Happy birthday to you! & Thank you. Don't forget to come. \\
Okay, bye! & See you. \\
\hline
\end{tabular}

Task1 : Form a pair in the class and make a dialogue with your friend with the help of clues given under:

$\begin{array}{lll}\text { Place } & : & \text { Home } \\ \text { People } & : & \text { You and your friend } \\ \text { Your Friend } & : & \text { Greets } \\ \text { You } & : & \text { Return greeting } \\ \text { Your Friend } & : & \text { Apologies for being late } \\ \text { You } & : & \text { Accept apology, ask for reason } \\ \text { Your Friend } & : & \text { Reason given } \\ \text { You } & : & \text { Suggest to join a party } \\ \text { Your Friend } & : & \text { Agrees } \\ \text { You } & : & \text { Offer cookies } \\ \text { Your Friend } & : & \text { Thanking } \\ \text { You } & : & \text { Responds }\end{array}$

\subsection{Role play}

Role play is a popular technique used in the classes to practice speaking skills in the class. There are three types of role plays - with clues, totally guided and free type.

Task1 (with clues): A traveller wants to reserve a ticket from Robe to Addis Ababa and he is at the bus station counter.

\begin{tabular}{|c|c|}
\hline Place & Bus station \\
\hline People & Traveller and the clerk \\
\hline $\begin{array}{l}\text { Role Play : } \\
\text { the place of boarding etc. }\end{array}$ & As a traveller you ask for the fare, time of departure, time of arrival, \\
\hline \multirow[t]{4}{*}{ Language } & Could you tell me \\
\hline & 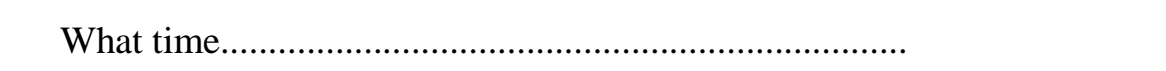 \\
\hline & 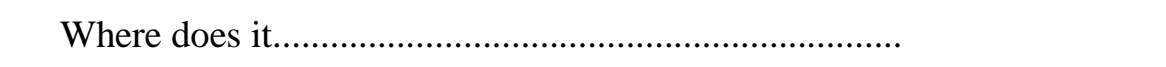 \\
\hline & 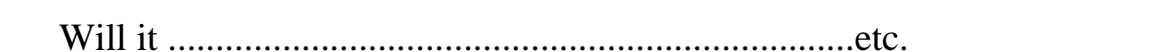 \\
\hline
\end{tabular}


Task 2 (Totally guided): To practice how to report 'wh' questions. Students will be guided to think that he had just returned from an interview and his father is asking how the interview was. The pair will play the role of father and son:

$\begin{array}{lll}\text { Father } & : & \text { Hi Dawit! } \\ \text { Son } & : & \text { Hi dad! } \\ \text { Father } & : & \text { How did the interview go? } \\ \text { Son } & : & \text { It was not bad } \\ \text { Father } & : & \text { Well, what did they ask you? } \\ \text { Son } & : & \text { They started with what my name was. } \\ \text { Father } \quad: & \text { Didn't they see your application? } \\ \text { Son } & \text { Y } \\ \text { wondered why } & \text { I wanted to give up the present job. The director asked how } \\ \text { working at my present job. } \\ \text { Father } \quad:\end{array}$

Task 3 (Free type): The teacher would instruct to play the following roles:

- Doctor and a patient in the hospital (in pair)

- Police inspector inquiring the neighbours of the burglary (4 people).

\subsection{Opinion/Ideas}

When we ask for opinions on controversial topics or situations, a lot of discussion can be generated. The learners may be divided into groups who discuss and come out with their opinions. Here, students have a lot of language to communicate their ideas.

Task: Discuss in your groups and come out with your opinions on the following statement:

"The present day youths are completely distracted from studies due to the internet."

\subsection{Problems (group work)}

Problems are good sources for making the learners speak. While engaged in gripping the problem, they have to use the language to solve it.

Task: Find out what it is:

- It has three eyes. It cannot see. It has food and water inside. The water is very sweet. It is very difficult to break it. What is it?

- It has a lot of teeth. It does not bite. It is made of plastic or wood. You stand in front of the mirror and use it every day. What is it?

\subsection{Surveys and Interviews}

This is also an interesting function based technique in which an interviewer or surveyor try to find out a person's test, preferences, attitudes, information etc.

Task (information activity): Students will be given census work. Now, develop a conversation with the people to get the information.

$\begin{array}{lll}\text { People : } & \text { Surveyor, family head } \\ \text { Place } \quad & \text { A house } \\ \text { Function : } & \quad \text { wh-questions and how }\end{array}$

\subsection{Visual Comprehension}

The learners will be provided a picture. After a careful observation they have to answer the questions asked by the teacher. 


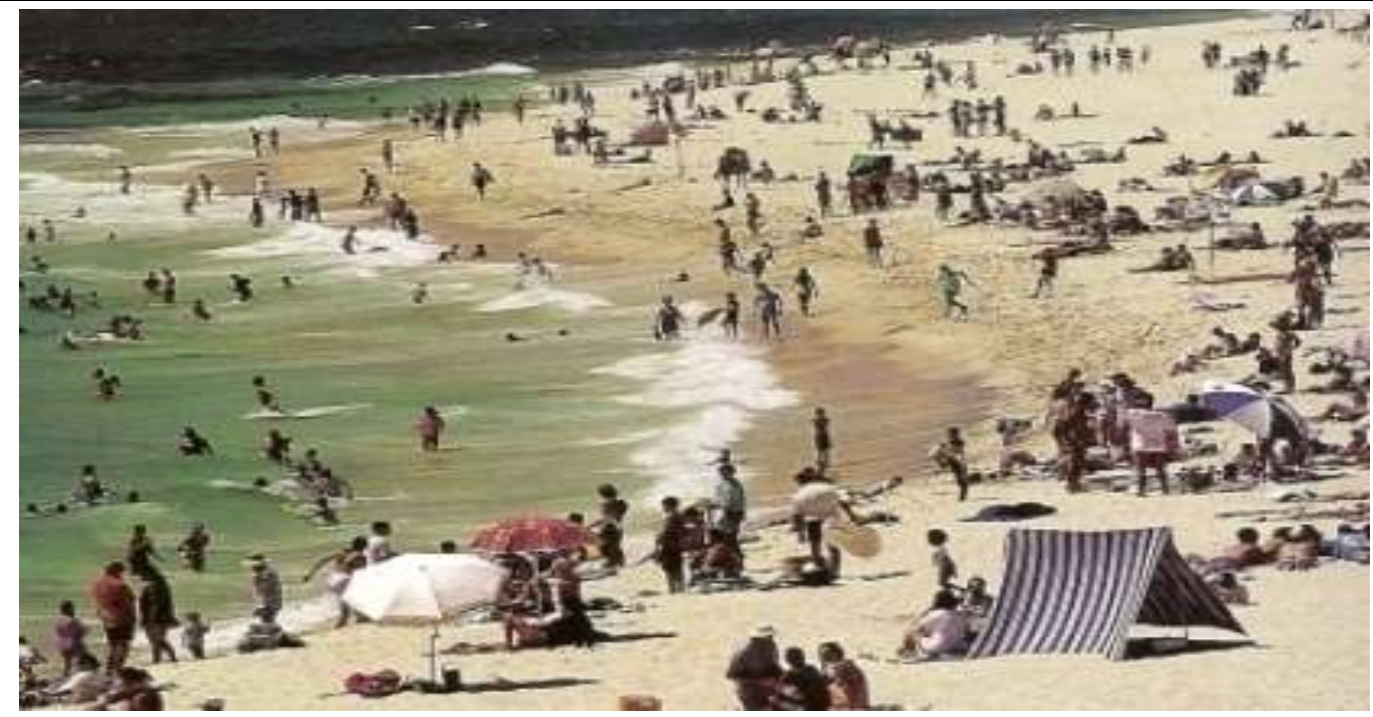

Figure3. Adapted from Kumari (2014)

Task (Questions):

- What do you see in this photograph?

- What are people doing?

- Have you ever seen or visited to this kind of landscape?

- What kinds of tourism sites are available in Ethiopia?

\subsection{Dreams or Ambitions}

Each learner has her own dreams and ambitions of life. This can be used as a good breeding point for interaction. The activity is open ended which leads to a lot of speaking. Students would be asked to look at these pictures and answer the questions:

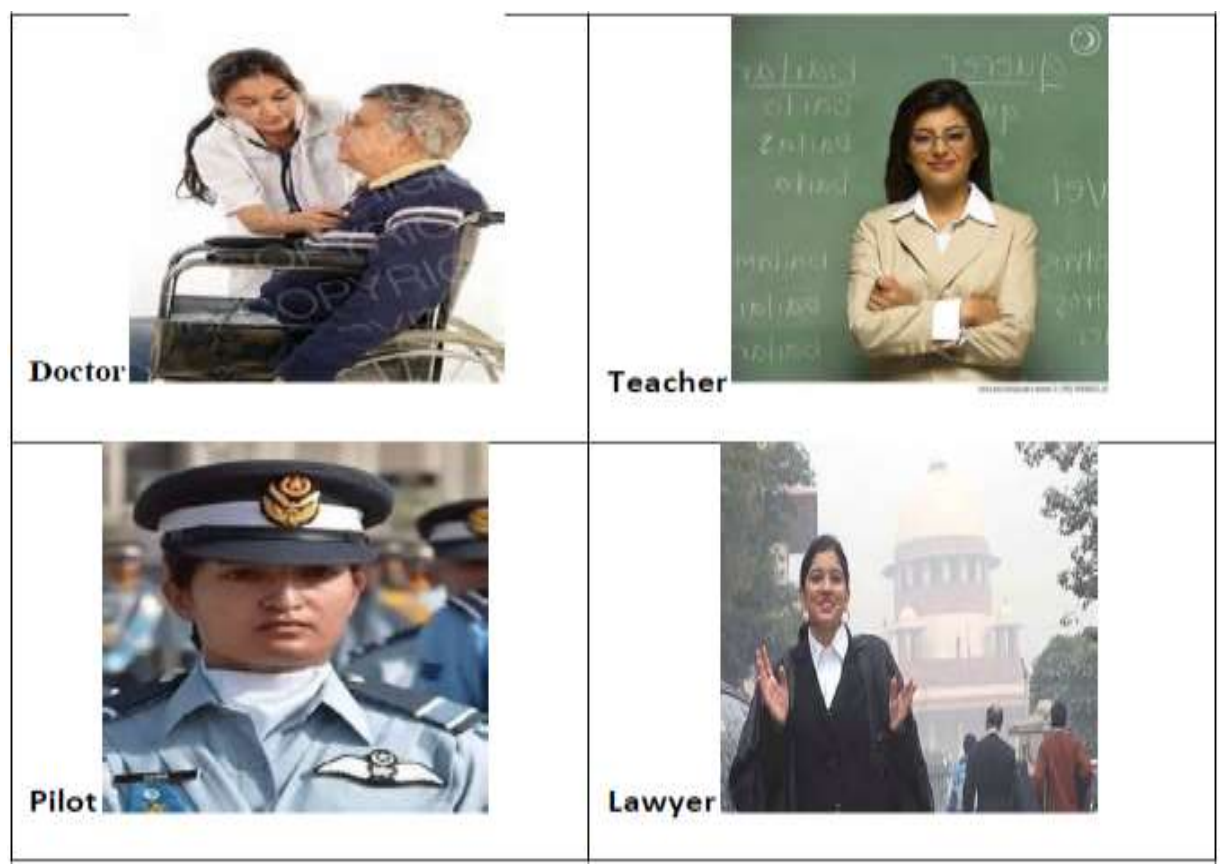

Figure4. Adapted from Kumari (2014)

Task (Questions):

- Is there any importance of dream in life?

- What is your dream of life?

- What is your ambition to do if you get your dream? 


\subsection{Rhymes and Tongue Twisters}

This is a play way method to acculturate English. We can teach learners through recitation of rhymes in an enjoyable manner. Finally, it adds value for speaking skill.

Task:

\begin{tabular}{|l|l|}
\hline \multicolumn{1}{|c|}{ Rhymes } & \multicolumn{1}{c|}{ Tongue Twisters } \\
\hline It's fun to be this & Betty bought some butter \\
It's fun to be that & But the butter was bitter \\
To leap like a lamp & So, Betty bought some better butter \\
To climb like a cat & To make the bitter butter better. \\
To swim like a fish & \\
To hop like a frog & \\
To trot like a horse & \\
To jump like a dog. & \\
\hline
\end{tabular}

\subsection{Songs}

The learners enjoy songs and it can be used for developing EFL speaking skill. For instance to practice simple question forms this may be beautifully used.

Tasks:

\begin{tabular}{|c|c|}
\hline Songs & Songs \\
\hline $\begin{array}{l}\text { 1. Who is Meena? What is she? } \\
\text { Is she a white little mouse? } \\
\text { Her teeth are white, her blouse is white, } \\
\text { But she is not a white little mouse. }\end{array}$ & $\begin{array}{l}\text { 2. Who is Meena? What is she? } \\
\text { Is she a black little bird? } \\
\text { Her eyes are black, Her hair is black } \\
\text { But she is not a black little bird. }\end{array}$ \\
\hline $\begin{array}{l}\text { 3. Who is Meena? What is she? } \\
\text { Is she a red little flower? } \\
\text { Her skirt is red, Her ribbons are red } \\
\text { But she is not a red little flower. }\end{array}$ & $\begin{array}{l}\text { 4. Who is Meena? What is she? } \\
\text { Meena is a girl, a pretty little girl } \\
\text { Meena is a pretty little girl. }\end{array}$ \\
\hline
\end{tabular}

Hence, a number of activities may be provided to the students to develop their speaking skills.

\section{TEACHERS' AND LEARNERS' ROLE}

\subsection{Teachers' Role}

According to Anuradha et al (2014), teachers play significant role in stimulating interactionand developing speaking skills. The roles are as follows:

- The teacher must be fluent and accurate in spoken elements of language so as to be a role model for the learners.

- The teacher asks questions to stimulate learners to practice the target language. Throwing questions and compelling them to answer something is one of the types of oral drills.

Further, encouraging students to ask questions to the teacher and peers is also a good technique to propel discussion and involve learners to speak.

\section{Examples}

How was your day?

(Answer)

Was yesterday Monday?

(Answer)

When will she come here?

(Answer)

Whose book is this?

(Answer)

Have you ever. ? (Answer)

- The teacher brings chart containing pictures in the classroom. Teaching aids like charts containing pictures are good stimulators of interaction in the classroom. The teacher highlights that part of the chart which breeds discussion in the class. 


\section{Example}

- The teacher brings a chart containing picture of a bakery. The model sentence is 'He wants to buy some bread.' If the teacher points to biscuits, students will say, 'He wants to buy some biscuits.' and so on.

- The teacher uses language laboratory (if available) for students speech practice through repetition whatever they listen with earphone.

\section{Example}

Learners sit at the booths that have one cassette player. The teacher plays the cassette and the learner listen the same. Afterwards, learners are asked to respond-repeating a word/phrase/sentence, answering a question and so on. The responses are recorded, the teacher listens it and notes down the weaknesses and strengths of the students and shows them directions.

- The teacher narrates a story or a joke in the classroom and evokes the learners to do the same. The narration is corrected by the students and the teacher if mistake is done. This way the interest to speak may be kindled among students.

- The teacher uses minimal pairs (pairs of words differing by one single sound) to teach some difficult sounds in the classroom with the help of familiar sounds of the students.

\section{Example}

The familiar sound / I /

bid

kid

tin

fist

lint
Sound to be learnt / 3: /

bird

curd

turn

first

learnt

- The teacher focuses more on oral drills. He introduces a language item and the learners situationalize it.

\section{Example}

Students listen and understand a language item (word, phrase or sentence) proposed by the teacher. An order is followed for oral practice - first in chorus, then in groups and then individually.

\subsection{Learners' Role}

Speaking is an art and to achieve it, students should:

- Be conversational and courteous in conventional greetings and other expressions.

- Ask questions and answer them too to maintain dialogue with other classmates and the teacher.

- Strive for building vocabulary, acquiring fluency and achieving accuracy.

- Make an attempt for better pronunciation, appropriate intonation and stress in the expressions of ideas and feelings.

\section{Teaching Pronunciation}

Pronunciation refers to speaking a languagewith appropriate stress, rhythm and intonation and it should be taught scientifically.Good pronunciation in a speech is an ornament of a person and a passport to the cultured society. The reasons of defective pronunciation of the learners of EFL are pronunciation discarded curriculum, absence of well pronounced teachers, and dearth of audio video aids, least listening environment and few difficult sounds (Sachdeva 2011).

\subsection{Principles of Teaching Pronunciation}

According to Sachdeva (2011), the principles of teaching pronunciation are as under:

- Pronunciation is learnt though imitation; therefore, the teacher should be a role model in pronunciation. He should be well versed in stress, rhythm and intonation practically. 
- The teacher should have the ability to compare the mother tongue of the learners with the sounds of English so that she can handle the peculiarities of ELT.

- The style of ELT should be natural.

- The speed of teacher's pronunciation should be moderate in ELT class.

\subsection{Activities to Improve Pronunciation}

Drills, minimal pairs, and reading aloud are some of the activities to improve the pronunciation.

\subsubsection{Pronunciation Drills}

There are two types of pronunciation drills - recognition drills and reproduction drills. The learners are firstly given a chance to recognise the sound and then they are asked to produce the sounds. Audio aids like record player can also be used for this purpose.

\subsubsection{Minimal pairs}

\begin{tabular}{|c|c|}
\hline A & B \\
\hline Pen & Pin \\
Tin & Thin \\
Tree & Three \\
\hline
\end{tabular}

\subsubsection{Explanation of Position of Different Organs of Speech}

Position of different organs of speech should be explained to the learners. Difference between mother tongue sounds and EFL sounds should be explained clearly.

\subsubsection{Reading Aloud}

It provides listening to the learners. The teacher selects such a text which is likely to be mispronounced by the learners. First students rectify the mistakes and if not, it will be done by the teacher. Good models of listening by L1 experts through tape record may be forwarded to students. Sufficient listening to good reading will help the students acquire excellent pronunciation (Suchdeva 2011).

\section{Conclusion}

Good pronunciation and fluency in speaking skill is the hallmark of culture and it is the duty of the teacher to accomplish this goal approximately as an Englishman does. Incessant effort is needed in this direction from the teachers and learners. The teachers should be given training in pronunciation. The syllabus should focus over the skill of speaking and pronunciation. The examinations should also tilt towards spoken abilities of the student. Then there is no reason that the students may fail to acquire good speaking skill and pronunciation.

\section{REFERENCES}

[1] Anuradha, RV, Raman, G, \&Hemamalini, HC. 2014. Methods of Teaching English. Hyderabad: Neelkamal Publications.

[2] Jyotsna, M\&Rao, SN.2009.Methods of Teaching English. Guntur: Sri Nagarjuna Publishers.

[3] Kumari, AV. 2014. Methods of Teaching English. Guntur: New Era Publications.

[4] Rao, VK. 2012. Techniques of Teaching English.Hyderabad:Neelkamal Publications.

[5] Suchdeva, MS. 2011. A New Approach to Teaching of English in India. Ludhiana: Tandon Publications. 